\title{
A correlational analysis of financial ratios of companies listed on the Mexican stock market in the period 2008-2017
}

\section{Un análisis correlacional de ratios financieros de empresas que cotizan en el mercado de valores mexicano en el periodo 2008-2017}

\author{
BERNAL-DOMINGUEZ, Deyanira*† \\ Universidad Autónoma de Sinaloa, Faculty of Accounting and Administration \\ ID $1^{\text {st }}$ Author: Deyanira, Bernal-Dominguez / ORC ID: 0000-0001-8990-1988, CVU CONACYT ID: 168056
}

DOI: $10.35429 / J M P C .2019 .16 .5 .1 .7$

Received July 20, 2019; Accepted December 30, 2019

\begin{abstract}
The objective of this investigation was to determine the correlation rates by economic sectors of companies that are listed on the Mexican stock market in the 2008-2017 period. The variables were: as dependent the financial ratio on operating profitability and as independent those of acid, financial cycle, working capital, net working capital, financial expense coverage, solvency ratio, short-term debt, accounts receivable days, inventory days, suppliers days, available, current assets turnover turnover, net fixed assets turnover and total assets turnover. To calculate the correlations, the financial information of 29 non-financial public companies in the Economática database was used. Correlation rates were calculated using bivariate linear regression analysis in the SPSS. The main findings are that in the sector of merchandise stores and department stores and in the sector of the beverage industry, significant positive correlation rates of 0.720 and 0.672 were obtained respectively. And three sectors with medium positive correlation which were residential building, food industry and the basic iron and steel industry. The most important relationship was between operating profitability and financial expense coverage.
\end{abstract}

Economic sectors, Linear regression, Financial ratios

\begin{abstract}
Resumen
El objetivo de esta investigación fue determinar los índices de correlación por sectores económicos de empresas que cotizan en el mercado de valores en México del periodo 2008-2017. Las variables fueron: como dependiente la razón financiera sobre rentabilidad operativa y como independientes las del ácido, ciclo financiero, circulante, capital neto de trabajo, cobertura de gastos financieros, coeficiente de solvencia, deuda a corto plazo, días cuentas por cobrar, días inventarios, días proveedores, disponible, endeudamiento rotación de activo circulante, rotación de activo fijo neto y rotación de activo total. Para calcular las correlaciones se utilizó la información financiera de 29 empresas públicas no financieras de la base de datos de Economática. Los índices de correlación se calcularon mediante análisis de regresión lineal bivariada en el SPSS. Los principales hallazgos es que en el sector de tiendas de mercancías y grandes almacenes y en el sector de la industria de las bebidas se obtuvieron índices de correlación positiva considerable de 0.720 y 0.672 respectivamente. Y tres sectores con correlación positiva media los cuales fueron edificación residencial, industria alimentaria y la industria básica del hierro y del acero. La relación más importante fue entre la rentabilidad de operación y la cobertura de gastos financieros.
\end{abstract}

Sectores económicos, Regresión lineal, Ratios financieros

Citation: BERNAL-DOMINGUEZ, Deyanira. A correlational analysis of financial ratios of companies listed on the Mexican stock market in the period 2008-2017. Journal of Microfinance Planning and Control. 2019, 5-16: 1-7

\footnotetext{
* Correspondence to Author (email: deyanirabernaldominguez@gmail.com)

$\dagger$ Researcher contributing first author.
} 


\section{Introduction}

The ratios of profitability, liquidity, working capital, average income per employee, cost, capital price and productivity are related to the growth of the company, providing valuable information for decision-making in the opinion of Ponikvar, Tajnikar \& Pusnik ( 2009); Likewise, Delen, Kuzey \& Uyar (2013) found through a sensitivity analysis using ROE (return on capital) as a dependent variable, that the earnings ratios before taxes on capital, the net profit margin, the leverage ratio, and the Sales Growth Index, respectively, have a greater impact on ROE prediction. The results in which the ROA (return on assets) was used as a dependent variable indicated that the most important financial ratios were earnings before taxes per share, the net profit margin, the ratio of indebtedness, and the turnover rate of assets, respectively, had a greater impact on ROA prediction. Concluding that the ratio of Earnings before taxes to Equity and net profit margin are the two most important variables to measure the performance of companies. Hence, operational profitability is resumed as a dependent variable of this study.

In Mexico, studies have been carried out on the relationships of business profitability with quantitative and qualitative data. Argüelles, Quijano, Fajardo \& Magaña in 2012 relate financial profitability with independent variables such as supervision, from internal control with descriptive and correlational approach in manufacturing analysis units in the city of San Francisco de Campeche, Mexico; confirming that it is feasible to consider supervision as an indicator that allows predicting financial profitability in an industrial company. Another finding was the one presented by Ibarra, Casas \& Barraza (2013) about the construction industry in the city of Hermosillo, Sonora, Mexico; explaining that the attractiveness of a sector that influences its profitability are price competitiveness, its cost structure and investment requirements. Likewise, financial ratios are used to define objectives, in studies of comparability with established standards, with other companies of the same business and with the sector average to make timely and efficient decisions; it should be mentioned that in Mexico the relevance of the publication of a financial ratios yearbook was demonstrated in the opinion of Bernal \& Saavedra in 2013.
Consequently, the contribution of this study is to find the relationships that impact profitability in Mexican companies. Hence, this study makes it possible to identify if the liquidity, debt, asset management and financial cycle ratios are correlated with the operating performance of the economic entity in question. In this way, monitoring these ratios will allow operational performance planning in for-profit companies.

Next, derived from the review of this research background related to the use of financial ratios and their impact on business profitability, the research question is stated:

1. Is there a relationship between the operating performance and the financial ratios of liquidity, indebtedness, asset management and financial cycle of the economic sectors in Mexico in the period 2008-2017?

The structure of this work is to raise a research question based on the background of the introductory part, then a theoretical justification of the variables by reviewing the literature, then the way in which the data for presentation and analysis were obtained. of the results, ending with the conclusions, discussion and limitations of the study.

\section{Review of the literature}

The improvement of corporate profitability through the study of the relationship with the cash cycle and working capital is demonstrated by Arcos \& Benavides (2008); The findings were the association between greater profitability with short cash cycles, lower indebtedness, minimizing the investment of working capital with proven axioms such as selling cash, minimizing inventories and buying on credit with the longest possible term.

Likewise, Yang \& Chuang (2010) propose an alternative model for the analysis of the dynamic adjustment process of financial ratios; This explains that the ratios of a company reflect the unexpected changes in the industry, the monitoring of management goals and the individual movement of the company. The model was applied with short-term liquidity, long-term solvency, short-term capital turnover, long-term capital turnover and return on investment ratios. 
This model improves the ability to explain its internal behavior with external changes such as financial crises or internal changes derived from management strategy adjustments. Coinciden, Alireza, Parvis \& Mina (2012), evaluate the ability of financial ratios to predict the financial crisis of companies. Financial reasons have more long-term predictive power, a finding shown by Jiang \& Lee in 2012, who conducted a study of cyclical and stochastic components analysis of financial ratios on dividend growth, income growth and accounting returns.

Yuh \& Gerab (2012), combined the techniques of Principal Component Analysis and Multiple Regression Analysis to know which factors impact the financial performance of the companies and which indicators most affect profitability; The main observations were that the most important factors in performance are the size of the company, gross margin, amount of capital, and the least decisive is financial leverage. The indicators that influence profitability are the management of working capital, liquidity, margin and financial debt.

On the other hand, Castillo \& García (2013) studied the factors that explain the profitability in wine companies of Castillo-De La Mancha, Spain. The hypothesis dealt with the variations in corporate profitability is based on the structure of the property, the size of the company, the financial structure and commercial strategies. They applied the main component technique. The main results were that profitability is higher in capitalist companies than in cooperatives; it is better in larger companies because they take advantage of economies of scale; the higher the proportion with own resources and liquidity, the profitability is higher.

The objective of this work is to know if the liquidity, indebtedness, asset management and economic cycle ratios explain the performance of the operating profitability based on the dictated accounting information of the companies listed on the Mexican Stock Exchange in the period 2008 -2017 grouped by economic sectors according to NAICS by its acronym in English (North American Industry Classification System).
The dependent variable is the operating performance ratio because it is considered a predictor of success. It is calculated considering in the numerator the retained earnings account, before interest and taxes (BAII) divided by the total assets, that is, between the investments necessary for the operation of the business.

The independent variables are liquidity, debt, asset management and financial cycle ratios. Table 1 shows the formulas of the financial ratios shown as dependent and independent variables.

Liquidity is defined as the company's ability to meet its short-term commitments. Debt ratios measure the level of debt compared to the contribution of the partners. The types of debt are measured with the short- and long-term debt ratios. The financial expense coverage ratio is applied to know how many times it is possible to cover interest with the performance of the main business activity.

The asset management ratios are integrated by the rotation of the total asset, net fixed asset and current assets, measuring the times in which these are recovered through sales; These ratios are considered solvency predictors, their monitoring avoids failure in companies and generates value (Altman, 1968; Amat, Leiva \& Graells, 2002; Mosqueda, 2004). Total asset turnover is the division of net sales among total assets; Asset turnover is equal to net sales divided by net fixed assets and current assets turnover, net sales between current assets. The variable that matches is net sales in the numerator. Another ratio is the economic cycle, this being the sum of the days it takes for the inventory to go out for sale and the days of recovery of accounts receivable. This sum is subtracted from the days it takes for the company to pay its suppliers. This cycle measured in days should be the shortest possible.

Therefore, the hypothesis of this research work is as follows:

H1. Operational profitability depends on the behavior of the financial liquidity, debt, asset management and financial cycle ratios in the economic sectors grouped by companies listed on the Mexican Stock Exchange in the period 2008-2017. 


\section{Methodology}

The financial information was consulted in the Economica database as of October 11, 2018. They were calculated based on the formulas of the financial ratios of 29 non-financial public companies listed on the Mexican Stock Exchange (BMV), every time, that Of the 78 companies available, only 29 had the total total assets data from 2008 to 2017 . The financial and insurance companies were not considered since they have different accounting regulations and ways of working that make them not assimilable to the rest of sectors included in the study. The data is analyzed in the SPSS with quantitative methodology applying bivariate linear regression analysis. Likewise, the Durbin Watson index is applied to measure autocolineality, considering as normal the results obtained between 1.5 and 2.5.

Next, the formulas of the financial ratios used for the calculation are presented, considering both the accounting accounts of the theory, as well as those charged by the economics system (Bernal and Amat, 2012):

The formulas of the ratios according to the theory are:

\section{Liquidity}

Circulating reason $=\frac{\text { Current Assets }}{\text { Current Liabilities }}$

Acid test $=\frac{\text { Current Assets }- \text { Inventories }}{\text { Current Liabilities }}$

Net Working Capital $=\frac{\text { Current Assets }- \text { Current Liabilities }}{\text { Current Liabilities }}$

Available $=\frac{\text { Cash and short-term investments }}{\text { Current Liabilities }}$

Solvency Coefficient $=\frac{\text { Total Liabilities }}{\text { Stockholders' equity }}$

\section{Indebtedness}

Indebtedness $=\frac{\text { Stockholders' equity }}{\text { Totally passive }}$

Short Term Debt $=\frac{\text { Passive in a short time }}{\text { Totally passive }}$

Financial Expense Coverage $=\frac{\text { EBIT }}{\text { Financial expenses }}$

\section{Asset Management}

Asset Rotation $=\frac{\text { Net sales }}{\text { Total active }}$
Asset Rotation $=\frac{\text { Net sales }}{\text { Net Fixed Assets }}$
Rotation of Current Assets $=\frac{\text { Net sales }}{\text { Current Assets }}$

Economic cycle

Inventory Days $=\frac{\text { Inventories } * 365}{\text { Sales cost }}$

Accounts Receivable Days $=\frac{\text { Accounts Receivable } * 365}{\text { Net sales }}$

Provider Days $=\frac{\text { Suppliers* } 365}{\text { Sales cost }}$

Financial Cycle $=$ Inventory Days

+ Accounts Receivable days

- Provider days

\section{Performance}

Operating Profitability $=\frac{\text { EBIT }}{\text { Total active }} * 100$

The formulas of the ratios according to the accounts of Economática are:

\section{Liquidity}

Circulating $=\frac{\text { Current active }}{\text { Current Liabilities }}$

Acid $=\frac{\text { Current Assets-Inventories }}{\text { Current Liabilities }}$

Net Working Capital $=\frac{\text { Current Assets-Current Liabilities }}{\text { Current Liabilities }}$

Available $=\frac{\text { Cash and Short Term Investments }}{\text { Current Liabilities }}$

Solvency Coefficient $=\frac{\text { Total Liabilities }}{\text { Consolidated Net Equity }}$

\section{Indebtedness}

Indebtedness $=\frac{\text { Consolidated Net Equity }}{\text { Total Liabilities }}$

Short Term Debt $=\frac{\text { Current Liabilities }}{\text { Total Liabilities }}$

Financial Expense Coverage $=\frac{\text { EBIT }}{\text { Financial expenses }}$ 


\section{Asset Management}

Asset Rotation $=\frac{\text { Net income }}{\text { Total active }}$
Asset Rotation $=\frac{\text { Net income }}{\text { Property, plant and Net Equipment }}$

Rotation of Current Assets $=\frac{\text { Net income }}{\text { Current active }}$

\section{Economic cycle}

Inventory Days $=\frac{\text { Inventories * } 365}{\text { Sales cost }}$

Accounts Receivable Days $=\frac{\text { Accounts Receivable } * 365}{\text { Net income }}$

Provider Days $=\frac{\text { Suppliers } * 365}{\text { Sales cost }}$

\section{Performance}

Operating Profitability $=\frac{\text { EBIT }}{\text { Total active }} * 100$

The information is presented by averages of four or more companies in the same sector; it is observed in table 1 that the sector that groups more companies is that of diverse merchandise stores and department stores with 10; that of the food industry with 6 , residential building 5 , beverage industry 4 , and finally the basic iron and steel industry with 4. Adding a total of 29 companies.

\begin{tabular}{|c|l|r|}
\hline Number & \multicolumn{1}{|c|}{ NAICS Sectors } & $\begin{array}{c}\text { Total } \\
\text { Companies }\end{array}$ \\
\hline 1 & Merchandise stores and department stores & 10 \\
\hline 2 & Food industry & 6 \\
\hline 3 & Residential building & 5 \\
\hline 4 & Beverage industry & 4 \\
\hline 5 & Basic iron and steel industry & 4 \\
\hline & Total Companies & $\mathbf{2 9}$ \\
\hline
\end{tabular}

Table 1 Classification of economic sectors according to NAICS

Source: Own elaboration based on Economic consultation (2018)

\section{Analysis of the results}

The average correlation rates are between 0.720 and 0.520 of the 5 economic sectors analyzed; according to figure 1 it is observed that 2 sectors present results with considerable positive correlation indexes; 0.720 and 0.672 , various merchandise stores and department stores and the beverage industry respectively. The sectors with average positive correlation indexes were the residential building with 0.605 , the food industry with 0.570 and the basic iron and steel industry with 0.520 .
This allows to consider the liquidity, debt, asset management and business cycle ratios for the projections of the operating profitability rate in companies Mexican from the exposed sectors.

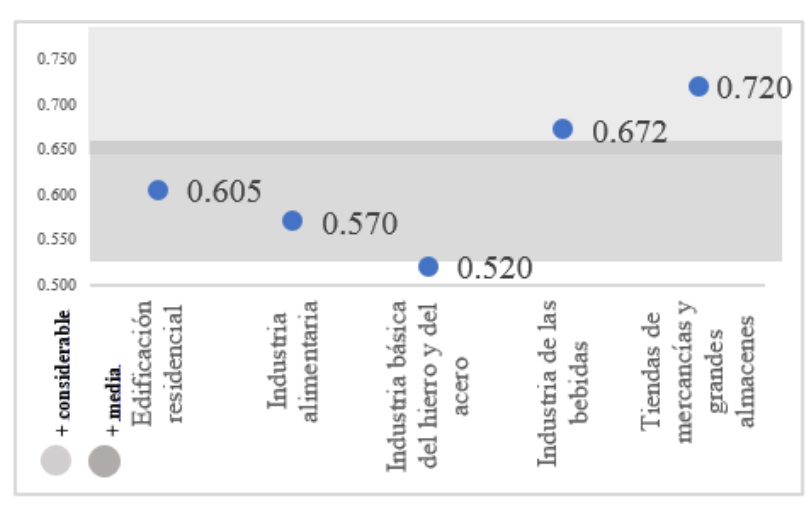

Figure 1 Strong positive correlation rates by economic sectors in Mexico. Period: 2008-2017

Source: Self Made

Table 2 shows the average financial ratios of each sector; It is observed that those with the highest correlation rates are: coverage of financial expenses, total asset turnover, shortterm debt, net working capital, turnover of net fixed assets, turnover of current and circulating assets. It is observed that the financial reasons for asset management are those with the highest correlation rates, as well as the debt and liquidity ratios.

\begin{tabular}{|c|c|c|c|}
\hline $\begin{array}{l}\text { Average } \\
\text { ratios }\end{array}$ & $\begin{array}{l}\text { Merchandise stores and } \\
\text { department stores }\end{array}$ & $\begin{array}{l}\text { Beverage } \\
\text { industry }\end{array}$ & $\begin{array}{l}\text { Residential } \\
\text { building }\end{array}$ \\
\hline GF coverage & 0.825 & 0.844 & 0.884 \\
\hline RotAT & 0.846 & 0.781 & 0.702 \\
\hline DebtCP & 0.738 & 0.735 & 0.679 \\
\hline CNT & 0.652 & 0.744 & 0.678 \\
\hline RotAFN & 0.728 & 0.613 & 0.430 \\
\hline RotAC & 0.771 & 0.695 & 0.583 \\
\hline Circulating & 0.741 & 0.696 & 0.649 \\
\hline Available & 0.626 & 0.659 & 0.637 \\
\hline CoefSolv & 0.656 & 0.672 & 0.515 \\
\hline CxC days & 0.704 & 0.647 & 0.465 \\
\hline In debt & 0.725 & 0.416 & 0.658 \\
\hline Acid & 0.669 & 0.667 & 0.402 \\
\hline Inv days & 0.573 & 0.406 & 0.634 \\
\hline Prov Days & 0.783 & 0.422 & 0.305 \\
\hline End Cycle & 0.646 & 0.000 & 0.574 \\
\hline AVERAGE & 0.712 & 0.600 & 0.586 \\
\hline GF coverage & 0.741 & 0.778 & 0.814 \\
\hline RotAT & 0.695 & 0.601 & 0.725 \\
\hline DebtCP & 0.502 & 0.672 & 0.665 \\
\hline CNT & 0.497 & 0.662 & 0.647 \\
\hline RotAFN & 0.594 & 0.804 & 0.634 \\
\hline RotAC & 0.473 & 0.567 & 0.618 \\
\hline Circulating & 0.354 & 0.574 & 0.603 \\
\hline Available & 0.610 & 0.443 & 0.595 \\
\hline CoefSolv & 0.669 & 0.422 & 0.587 \\
\hline CxC days & 0.542 & 0.439 & 0.559 \\
\hline In debt & 0.615 & 0.369 & 0.557 \\
\hline Acid & 0.456 & 0.544 & 0.548 \\
\hline Inv days & 0.547 & 0.460 & 0.524 \\
\hline Días Prov & 0.640 & 0.249 & 0.480 \\
\hline End Cycle & 0.571 & 0.410 & 0.440 \\
\hline AVERAGE & 0.567 & 0.533 & 0.600 \\
\hline
\end{tabular}

Table 2 Correlation rates between operating profitability and financial liquidity, debt, asset management and financial cycle ratios

Source: Self Made

BERNAL-DOMINGUEZ, Deyanira. A correlational analysis of financial ratios of companies listed on the Mexican stock market in the period 2008-2017. Journal of Microfinance Planning and Control. 2019 
Finally, Figure 2 is presented where it is observed that the Corporate Fragua, which is dedicated to the purchase and sale of medicines, perfumery and others, with the identity of Guadalajara Pharmacies is the one that presents a positive correlation between the dependent variable, operating profitability with the 15 independent variables which are all the ratios applied to liquidity, indebtedness, asset management and economic cycle. It is followed in importance, the food industry with Bachoco and merchandise store like Elektra, with 14 ratios.

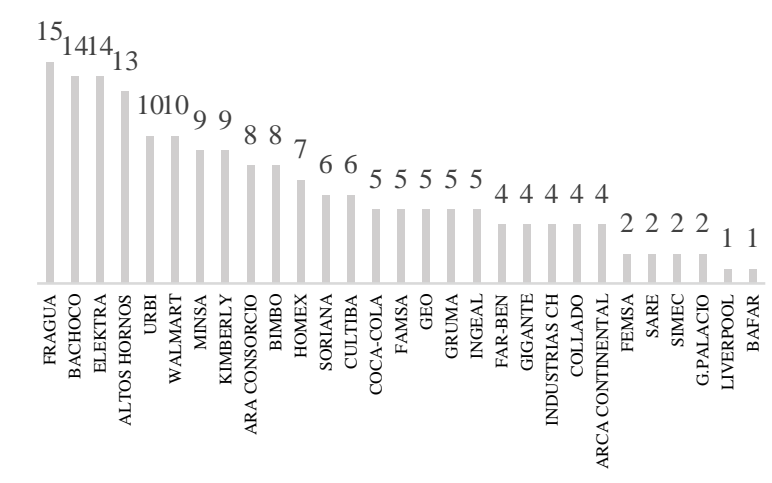

Figure 2 Number of ratios by Mexican companies that present positive correlation indexes greater than or equal to 0.5 , with Durbin Watson between 1.5 and 2.5. Period: 2008-2017

Source: Self Made

\section{Conclusions}

Operational profitability depends on the behavior of the financial liquidity, debt, asset management and financial cycle ratios in the five economic sectors in Mexico analyzed, so the hypothesis of this research is tested. All economic sectors studied showed significant positive correlations and means. The first were the companies that are dedicated to various merchandise stores and department stores and the beverage industry.

Mention separately, the financial ratios with the highest average correlation rates were: coverage of financial expenses, total asset turnover, short-term debt, net working capital, net fixed asset turnover, current and current asset turnover; it is observed that these results coincide in part with the findings of Yuh \& Gerab (2012) who find that the indicators that influence profitability are liquidity, margin and financial debt; Arcos \& Benavides in 2008 showed that the lower the cash cycles and the better indebtedness will be the profitability.
In addition, Castillo \& García in 2013 also considered liquidity as a determinant in increasing the profit margins of businesses. The main limitation of this work is access to the financial information of Mexican companies. Therefore, the information was collected based on the accounting reports of 29 public companies listed on the stock market in the country represented by 5 sectors; leaving out of the study 8 sectors for being integrated by a single company or for not having the financial information required for the calculation of the ratios; reason why these averages were not calculated.

Finally, it is recommended to carry out future research on the design of a profitability model for non-public and smaller companies which represent more problems in the way of managing and making managerial decisions; the project would be from the main accounts of the ratios with the highest correlation rates, which would include the following variables: EBIT (Earnings Before Interest and Taxes), total assets, current assets, net fixed assets, total liabilities, stockholders' equity, net sales and financial expenses. Likewise, the possibility of carrying out studies on correlations between profitability and independent variables such as internal control levels, company size, climate of the organization, intangible assets, growth of the economy, behavior of costs, of inflation prices and indices, supported by the findings of Castillo \& García (2013), who also consider that factors such as the size of the company and the structure of the property explain the profitability; as well as for Alireza, Parvis \& Mina (2012) argue that financial ratios are also predictors of financial crises in organizations.

\section{References}

Alireza, F., Parviz, M., \& Mina, S. (2012). Evaluation of the Financial Ratio Capability to Predict the Financial Crisis of Companies. IUP Journal Of Behavioral Finance, 57-69.

Altman, E. (1968). Financial Ratios, Discriminant Analysis and the Prediction of Corporate Bankruptcy. The Journal of Finance. Vol. 23, No. 4, pp. 589-609.

Amat, O.; Leiva, LI. \& Graells, J., (2002) Ratios sectoriales. Ediciones Gestión 2000. Barcelona. España. 
Arcos M, A., \& Benavides F, J. (2008). Efecto del ciclo de efectivo sobre la rentabilidad de las firmas Colombianas. Cuadernos de Administración, 21(36), 167-182. Retrieved June 27, 2014, from http://www.scielo.org.co/scielo.php?script=sci_ arttext\&pid $=$ S0120

$35922008000200008 \& \operatorname{lng}=e n \& t \operatorname{lng}=e s$. .

Argüelles Ma, L., Quijano G, A., Fajardo, J, M., \& Magaña M, D. (2012). La supervisión, su impacto en la rentabilidad financiera de las pymes. sector manufacturero. (Spanish). Global Conference On Business \& Finance Proceedings, 7(2), 870-874.

Bernal, D. D \& Amat, O. (2012). Anuario de ratios financieros sectoriales en México para análisis comparativo empresarial. Revista Raximhai, 8, 271-286.

Bernal, D.D. \& Saavedra, G. M. (2013). “ Nivel de uso del análisis financiero de empresas en México y la necesidad de contar con un anuario de ratios financieros. Congreso Anual AEDEM, Universidad de Huelva, España.

Castillo, V, J.S. \& García, C, M.C. (2013). Análisis de los factores explicativos de la rentabilidad de las empresas vinícolas de Castilla- La Mancha. Rev. FCA UNCUYO. 45(2): 141-154

Delen, D.; Kuzey, C. \& Uyar, A. (2013). Measuring firm performance using financial ratios: A decision tree approach. Expert Systems with Applications. http://dx.doi.org/10.1016/j.eswa.2013.01.012

Ibarra, L., Casas, E. \& Barraza, K. (2013). La Rentabilidad del Sector Industrial de la Construcción en Hermosillo, Sonora, a partir del Análisis Holístico de las Cinco Fuerzas Competitivas de Porter. Revista Global de Negocios. Volumen 1, Número 1, 2013. ISSN 2328-4641 (print).

Jiang, X. \& Lee, B. (2012). Do Decomposed Financial Ratios Predict Stock Returns and Fundamentals Better?. Financial Review, 47(3), 531-564. doi:10.1111/j.1540-
Mosqueda R. (2004). Propuesta de un ratio ponderado de valoración empresarial. IV Workshop de Investigación Empírica en Contabilidad Financiera, Universidad de Sevilla. Revisada el 22 de octubre de 2011. http://www.aloj.us.es/arquero/docs/15.pdf

Ponikvar, N., Tajnikar, M., \& Pusnik, K. (2009). Performance Ratios for Managerial DecisionMaking in a Growing Firm. Journal Of Business Economics And Management, 10 (2), 109-120.

Yang Y. y Chuang, H.W. (2010). A Dynamic Financial Ratio Adjustment Model. Global Journal of Business Research (GJBR), 4(3), 110.

Yuh, H. C., y Gerab, F. (2012). Determinants Of Financial Performance In Brazilian Companies: A Multi-Ratio Model Using Multivariate Statistical Method. Journal Of Global Business \& Economics, 5(1), 79-99.

\section{Software}

Economatica de México SPSS 24 